Levitsky A. P., Markov A. V., Pupin T. I. Development of dysbiosis in the organism of rats receiving a high-fat diet. Journal of Education, Health and Sport. 2020;10(4):199-208. eISSN 2391-8306. DOI http://dx.doi.org/10.12775/JEHS.2020.10.04.022

https://apcz.umk.pl/czasopisma/index.php/JEHS/article/view/JEHS.2020.10.04.022

https://zenodo.org/record/3776359

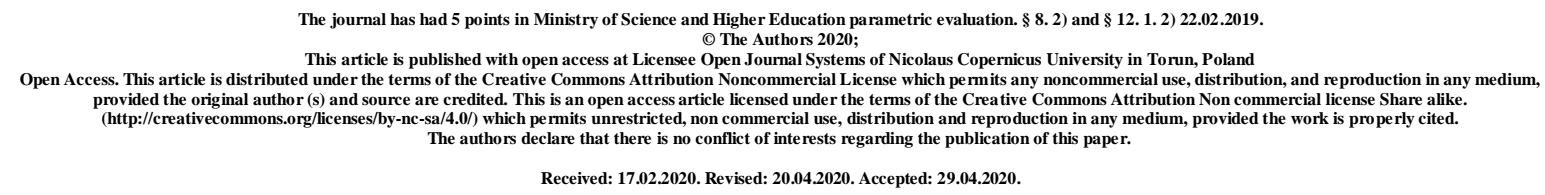

UDK 616.34:615.874

\title{
DEVELOPMENT OF DYSBIOSIS IN THE ORGANISM OF RATS RECEIVING A HIGH-FAT DIET
}

\author{
A. P. Levitsky', A. V. Markov², T. I. Pupin ${ }^{2}$ \\ 10dessa National Academy of Food Technologies \\ ${ }^{2}$ Lviv National Medical University named after Danylo Galytskij \\ irina.selivanskaya@gmail.com
}

\section{Abstract}

Background. To determine the effect on the degree of dysbiosis in the organs and tissues of rats treated with high-fat diet (HFD) using fats with various fatty acid compositions.

Methods. We used ordinary (high-linoleic) sunflower oil, high-oleic sunflower oil, butter, palm and coconut oils. Rats were fed with $15 \%$ of each of the fats for 64 days. In the blood serum from v.cava and v. porta, in the liver, heart, brain, skeletal muscles and intestinal mucosa, urease activity (an indicator of bacterial insemination), lysozyme activity (a factor of non-specific immunity) were determined, and the degree of dysbiosis was calculated from the ratio of relative urease and lysozyme activities.

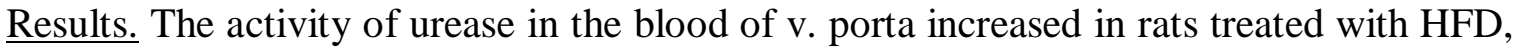
and was significantly higher than in the blood of v.cava. In most of the studied tissues, urease activity increased after HFD, with the exception of rats receiving high-oleic sunflower oil (HOSO). In contrast, lysozyme activity was reduced in most tissues, with the exception of rats 
treated with HOSO. The degree of dysbiosis increased after HFD with the exception of rats treated with HOSO.

Conclusion. HFD increases the translocation of bacteria from the intestine. The liver partially neutralizes the microflora coming from the intestines. In blood serum from v. cava and v. porta, urease activity (an indicator of bacterial contamination), lysozyme activity (nonspecific immunity factor) were determined in the liver, heart, brain, skeletal muscle and intestinal mucosa, and the degree of dysbiosis was calculated by the ratio of the relative activities of urease and lysozyme.

Results. Blood urease activity v. porta was elevated in rats treated with HFD and was significantly higher than in blood v. cava. In most of the tissues studied, urease activity increased after HFD with the exception of rats treated with high oleic sunflower oil (HOSO), the development of dysbiosis in all tissues of the body. The exception is HOSO, which does not cause the development of dysbiosis and inflammation.

Key words: high-fat diet; dysbiosis; urease; lysozyme; liver; high oleic sunflower oil.

\section{INTRODUCTION}

It is known that highfat diet (HFD) affects the condition of the intestinal microbiota, causing the development of dysbiosis [1-3]. Food fats with high palmitic acid content have been found to have the greatest influence on the development of intestinal dysbiosis [4-6].

Given that the endogenous microbiota is found not only in the intestine, but in all tissues without exception [7-9], a priori it is possible to consider as a possible change the state of the microbiota in different tissues of the organism under conditions of HFD.

Therefore, the aim of our work was to investigate the effect of HFD using food fats, different in their fatty acid composition, on bacterial insemination, the level of nonspecific immunity determined by the activity of the lysozyme enzyme, and the degree of dysbiosis calculated by A. P. Levitsky [10].

\section{MATERIAL AND RESEARCH METHODS}

The following fats were used in the work: ordinary (highlinoleic) sunflower oil, high-oleic olive oil "Olivka", butter, palm oil and coconut oil. The characterization of these fats is presented in our previous work [11]. Thus, in ordinary sunflower oil the main fatty acid is linoleic $\left(\mathrm{C}_{18: 2}\right)-$ 
more than $53 \%$, in high-oleic sunflower oil "Olivka" the main acid is oleic $\left(\mathrm{C}_{18: 1}\right)-88 \%$, in butter $(29 \%)$ contains oleic and palmitic $\left(\mathrm{C}_{16: 0}\right)$ acids and almost $25 \%$ of medium-chain and short-chain fatty acids. In palm oil, $42 \%$ is palmitic acid and $41 \%$ is oleic, while in coconut oil, more than $46 \%$ is lauric acid $\left(\mathrm{C}_{12: 0}\right)$ and there are practically no polyunsaturated fatty acids.

Experiments on highfat diet were carried out on 36 white Wistar rats (males, 8-9 months, live weight 240-260 g), divided into 6 equal groups. Group 1 (control) received standard feed containing $5 \%$ fat [12], Groups 2, 3, 4, 5 and 6 received compound feeds in which $15 \%$ of the grain component was replaced for the appropriate fat: 2nd - ordinary sunflower oil, 3rd "Olivka", 4th - butter, 5th - palm oil and 6th - coconut oil. The rats had no restriction in feed and water, and the duration of the HFD was 64 days.

Before euthanasia, the animals were given blood from v. porta and v. cava inferior, and then, after euthanasia, organs and tissues were selected for biochemical studies, namely liver, small and large intestine mucous membranes, heart, skeletal muscle, brain. Animal euthanasia was performed under thiopental anesthesia $(20 \mathrm{mg} / \mathrm{kg}$ ) by total bleeding from the heart.

The activity of the bacterial enzyme urease (indicator of microbial insemination) [13], the activity of the antimicrobial enzyme lysozyme (indicator of the state of nonspecific immunity) were determined in serum and tissue homogenate [14]. According to the ratio of relative activities of urease and lysozyme, the degree of dysbiosis according to A. P. Levitsky was calculated [10].

The results of the experiments were subjected to standard statistical processing [15].

\section{RESULTS AND DISCUSSION}

Table 1 presents the results of determining the activity of urease in serum from $\mathrm{v}$. porta and v. cava. From these data, it can be seen that HFD increases the activity of urease in serum from v. porta, which may indicate an increase in bacteremia, especially after consumption of conventional sunflower and palm oil and butter. The lowest level of bacteremia was found when consuming higholeic sunflower oil.

In serum from v. cava urease activity tends to decrease, with rats treated with HFD using higholeic sunflower oil up to the control level.

On the basis of these data, we can assume that the liver retains almost 30-40\% of urease, which enters the liver from v. porta. 
Table 1. Effect of HFD on serum urease activity with v. porta and v. cava of rats $(n=6)$

\begin{tabular}{|c|c|c|c|c|c|}
\hline \multirow{2}{*}{ №№ } & \multirow{2}{*}{ Fats } & \multicolumn{2}{|c|}{ Urease, nkat / 1 (A) } & \multirow{2}{*}{$\Delta \mathrm{A}$} & \multirow{2}{*}{$\begin{array}{l}\% \text { of A y } \\
\text { v. porta }\end{array}$} \\
\hline & & $\mathrm{v}$. porta & v. cava & & \\
\hline 1 & Control & $1,04 \pm 0,43$ & $\begin{array}{c}0,62 \pm 0,35 \\
\mathrm{p}_{1}>0,3\end{array}$ & $-0,42 \pm 0,32$ & $-40,4$ \\
\hline 2 & Sunflower oil & $\begin{array}{c}1,97 \pm 0,16 \\
\mathrm{p}<0,05\end{array}$ & $\begin{array}{c}1,50 \pm 0,49 \\
\mathrm{p}>0,05 ; \mathrm{p}_{1}>0,05\end{array}$ & $-0,47 \pm 0,27$ & $-23,8$ \\
\hline 3 & $\begin{array}{l}\text { High-oleic } \\
\text { sunflower oil }\end{array}$ & $\begin{array}{c}1,44 \pm 0,60 \\
p>0,3\end{array}$ & $\begin{array}{c}0,62 \pm 0,46 \\
p=1 ; p_{1}>0,05\end{array}$ & $-0,82 \pm 0,36$ & $-56,9$ \\
\hline 4 & Butter & $\begin{array}{c}2,06 \pm 0,70 \\
\mathrm{p}>0,05\end{array}$ & $\begin{array}{c}1,23 \pm 0,40 \\
\mathrm{p}>0,05 ; \mathrm{p}_{1}>0,05\end{array}$ & $-0,83 \pm 0,41$ & $-40,3$ \\
\hline 5 & Palm oil & $\begin{array}{c}2,61 \pm 0,24 \\
\mathrm{p}<0,05\end{array}$ & $\begin{array}{c}1,38 \pm 0,35 \\
\mathrm{p}>0,05 ; \mathrm{p}_{1}<0,05\end{array}$ & $-1,23 \pm 0,29$ & $-47,1$ \\
\hline 6 & Coconut oil & $\begin{array}{c}1,84 \pm 0,36 \\
\mathrm{p}>0,05\end{array}$ & $\begin{array}{c}1,25 \pm 0,52 \\
p>0,05 ; p_{1}>0,05\end{array}$ & $-0,59 \pm 0,38$ & $-32,1$ \\
\hline
\end{tabular}

Notes: $\mathrm{p}$ - compared with gr. 1 (control); $\mathrm{p}_{1}$ - compared with A in v. porta.

Table 2 presents the results of determination in the serum of rats of lysozyme activity. The data obtained show that both sunflower oils do not affect the level of lysozyme in the blood v. porta, while butter, palm and coconut oil significantly reduce the level of lysozyme. In serum from v. cava lysozyme activity differs little from serum activity v. porta except for rats treated with palm oil.

Table 2. Effect of HFD on serum lysozyme activity with v. porta and v. cava of rats $(n=6)$

\begin{tabular}{|c|c|c|c|c|c|}
\hline \multirow{2}{*}{ №№ } & \multirow{2}{*}{ Fats } & \multicolumn{2}{|c|}{ Lysozyme, units / 1 (A) } & \multirow{2}{*}{$\Delta \mathrm{A}$} & \multirow{2}{*}{$\begin{array}{l}\% \text { from } A \\
y \text { v. porta }\end{array}$} \\
\hline & & v. porta & v. cava & & \\
\hline 1 & Control & $71 \pm 3$ & $\begin{array}{c}66 \pm 3 \\
p_{1}>0,2\end{array}$ & $-5 \pm 1$ & $-7,0$ \\
\hline 2 & Sunflower oil & $\begin{array}{l}73 \pm 6 \\
p>0,3\end{array}$ & $\begin{array}{c}76 \pm 2 \\
p<0,05 ; p_{1}>0,3\end{array}$ & $+3 \pm 1$ & $+4,1$ \\
\hline 3 & $\begin{array}{l}\text { High-oleic } \\
\text { sunflower oil }\end{array}$ & $\begin{array}{l}79 \pm 5 \\
p>0,1\end{array}$ & $\begin{array}{c}68 \pm 3 \\
p>0,3 ; p_{1}>0,05\end{array}$ & $-11 \pm 3$ & $-13,9$ \\
\hline 4 & Butter & $\begin{array}{c}59 \pm 4 \\
p<0,05\end{array}$ & $\begin{array}{c}55 \pm 3 \\
\mathrm{p}<0,05 ; \mathrm{p}_{1}>0,3\end{array}$ & $-4 \pm 1$ & $-6,8$ \\
\hline 5 & Palm oil & $\begin{array}{c}45 \pm 4 \\
p<0,05\end{array}$ & $\begin{array}{c}15 \pm 1 \\
\mathrm{p}<0,05 ; \mathrm{p}_{1}<0,05\end{array}$ & $-30 \pm 2$ & $-66,7$ \\
\hline 6 & Coconut oil & $\begin{array}{c}38 \pm 2 \\
\mathrm{p}<0,05\end{array}$ & $\begin{array}{c}44 \pm 3 \\
\mathrm{p}<0,05 ; \mathrm{p}_{1}>0,05\end{array}$ & $+6 \pm 1$ & $+15,8$ \\
\hline
\end{tabular}

Notes: see tab. 1. 
In Fig. 1 and 2 present the results of the determination of urease activity in organs and tissues of rats treated with HFD. As can be seen from these data, the level of urease in the liver increases significantly with the consumption of palm and coconut oils, in the mucous membrane of the small intestine significantly increases with the consumption of conventional sunflower oil, palm and coconut oils.

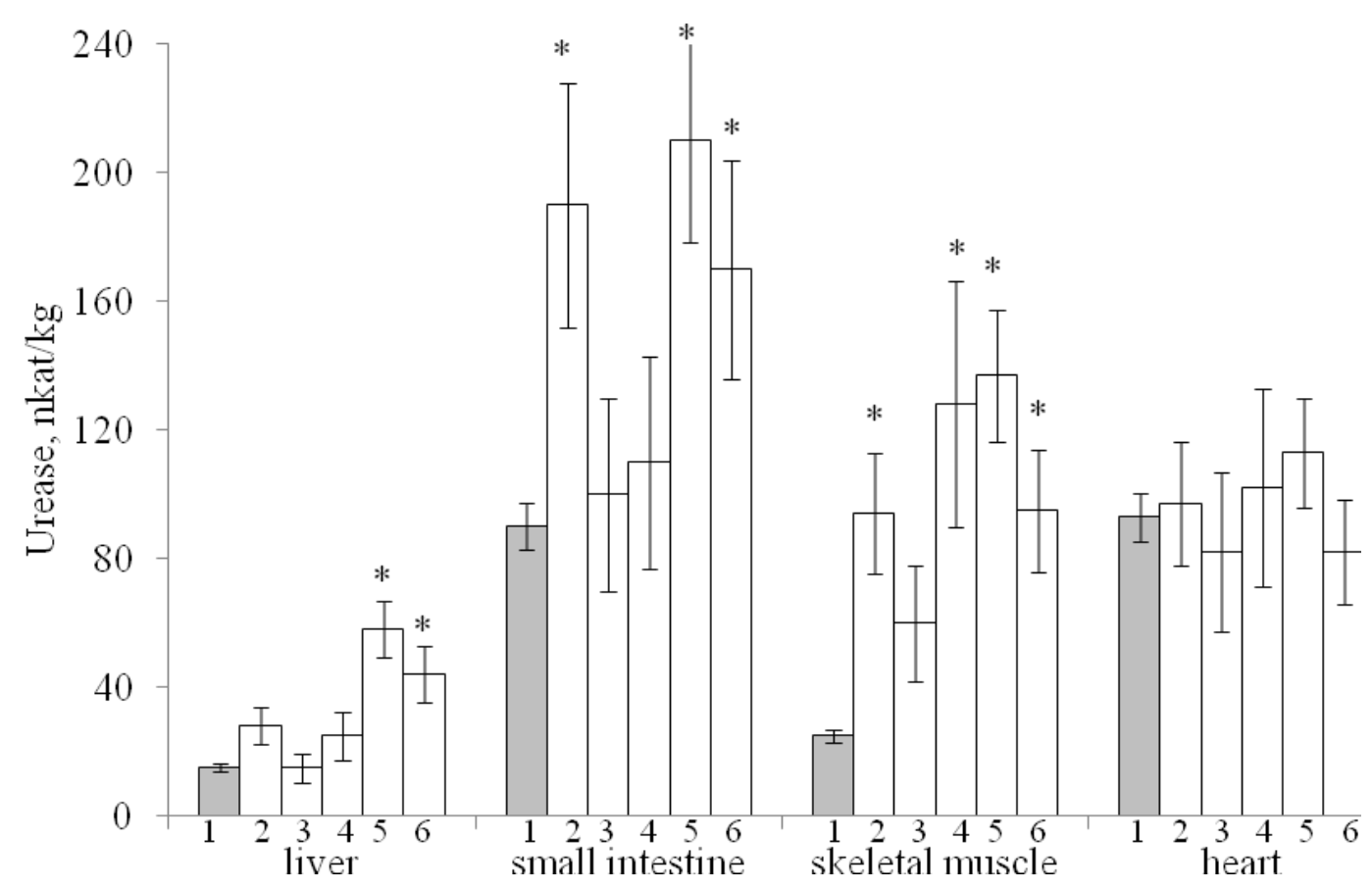

Fig. 1. Effect of HFD on urease activity in organs and tissues of rats (1 - control, 2 - sunflower oil, 3 - high-oleic sunflower oil, 4 - butter, 5 - palm oil, 6 - coconut oil)

In skeletal muscle, urease activity increases significantly with the consumption of all oils except high-oleic sunflower oil.

There were no significant changes in urease activity in the heart of rats receiving HFD.

In the tissue of the brain, a significant increase in the urease level is observed in rats treated with HFD using conventional sunflower oil, butter and palm oil.

In the large intestinal mucosa, a significant increase in urease activity was observed in rats treated with butter or palm oil. 
The data we have obtained indicate that HFD causes an increase in bacterial insemination in almost all tissues and organs studied. The exception is high-oleic sunflower oil, which consumption does not increase the activity of urease in the body.

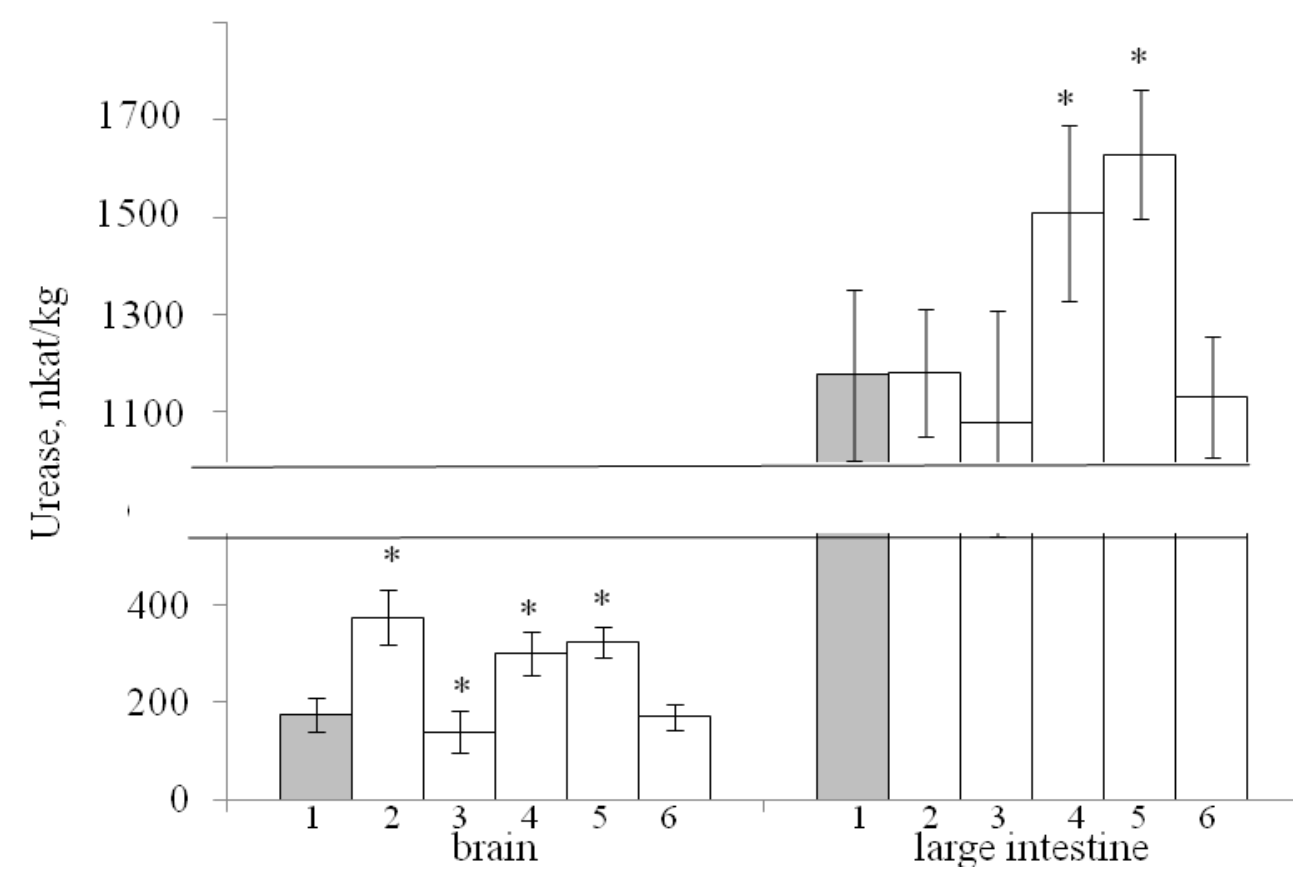

Fig. 2. Effect of HFD on urease activity in organs and tissues of rats (1-6- see Fig. 1)

In Fig. 3 and 4 present the results of determining in the organs and tissues of rats the activity of lysozyme. From these data, it is clear that HFD differently affects the level of this enzyme. Most tissues and organs have a clear tendency to decrease lysozyme activity.

In the liver butter significantly reduces the activity of lysozyme, in the small intestinal mucosa in all rats decreases the activity of lysozyme except rats treated with high-oleic sunflower oil, in the mucous membrane of the colon significantly reduce the activity of lysozyme butter, palm and coconut oil. These same fats reduce the activity of lysozyme in the brain. In the heart, lysozyme activity is reduced by palm and coconut oil, while in skeletal muscle both sunflower oils significantly increase lysozyme activity.

Analyzing our results, we can state that in relation to the activity of lysozyme, high-oleic sunflower oil never reduces this indicator of the state of nonspecific immunity. 


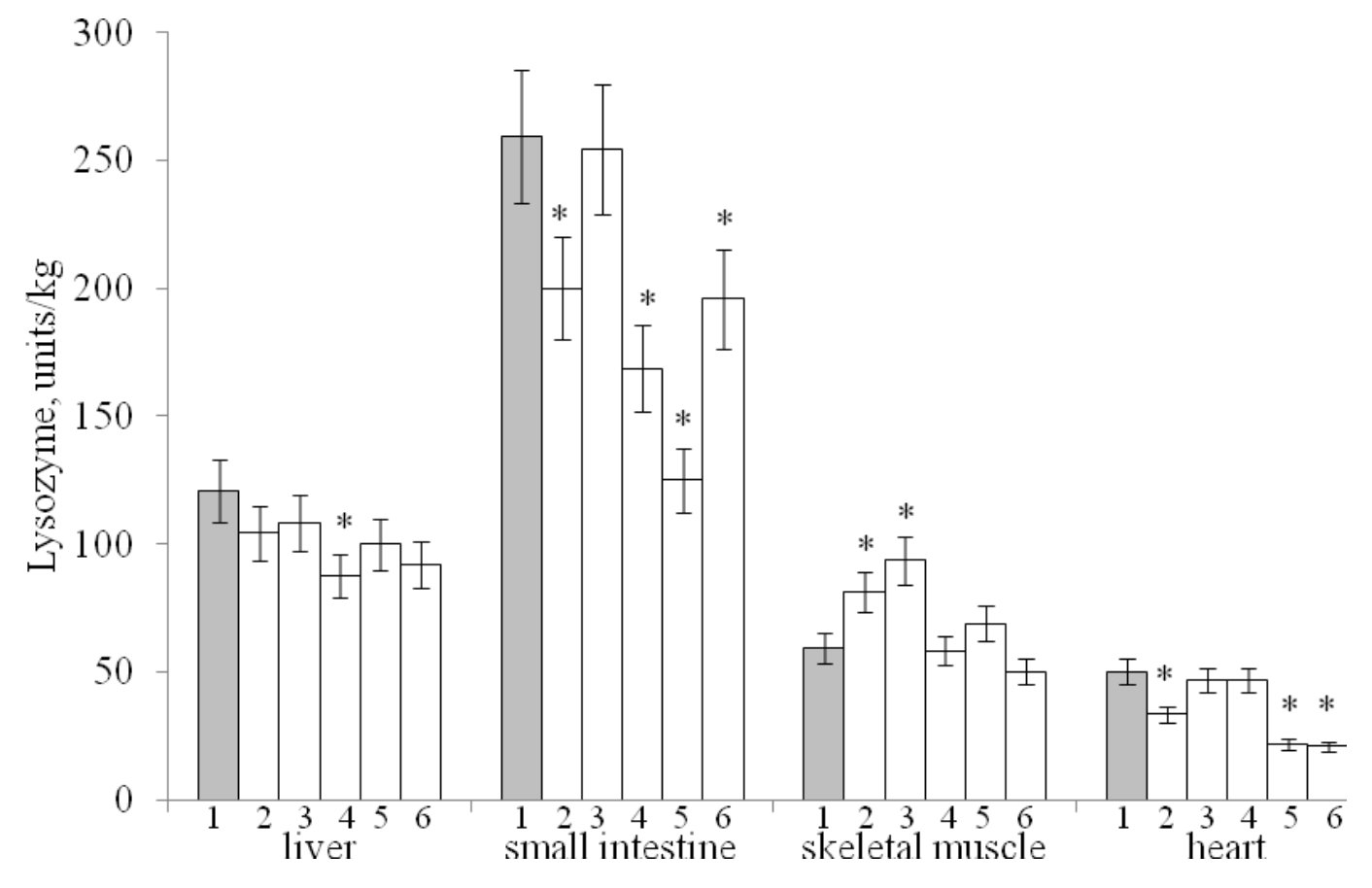

Fig. 3. Effect of HFD on lysozyme activity in rat organs and tissues (1-6 - see Fig. 1)

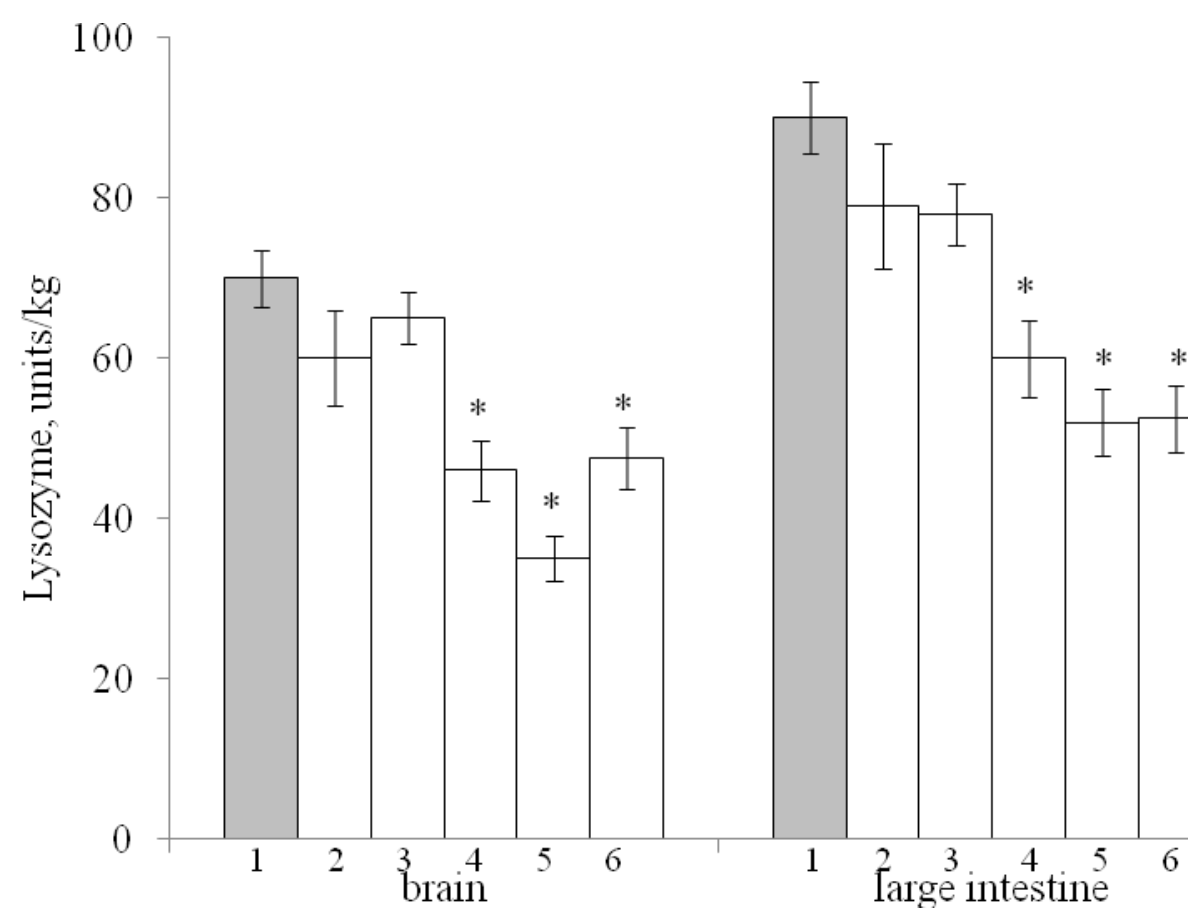

Fig. 4. Effect of HFD on lysozyme activity in rat organs and tissues (1-6 - see Fig. 1) 
The degree of dysbiosis in the organs and tissues of rats receiving HFD is calculated by us according to the method of A. P. Levitsky 5 and 6.

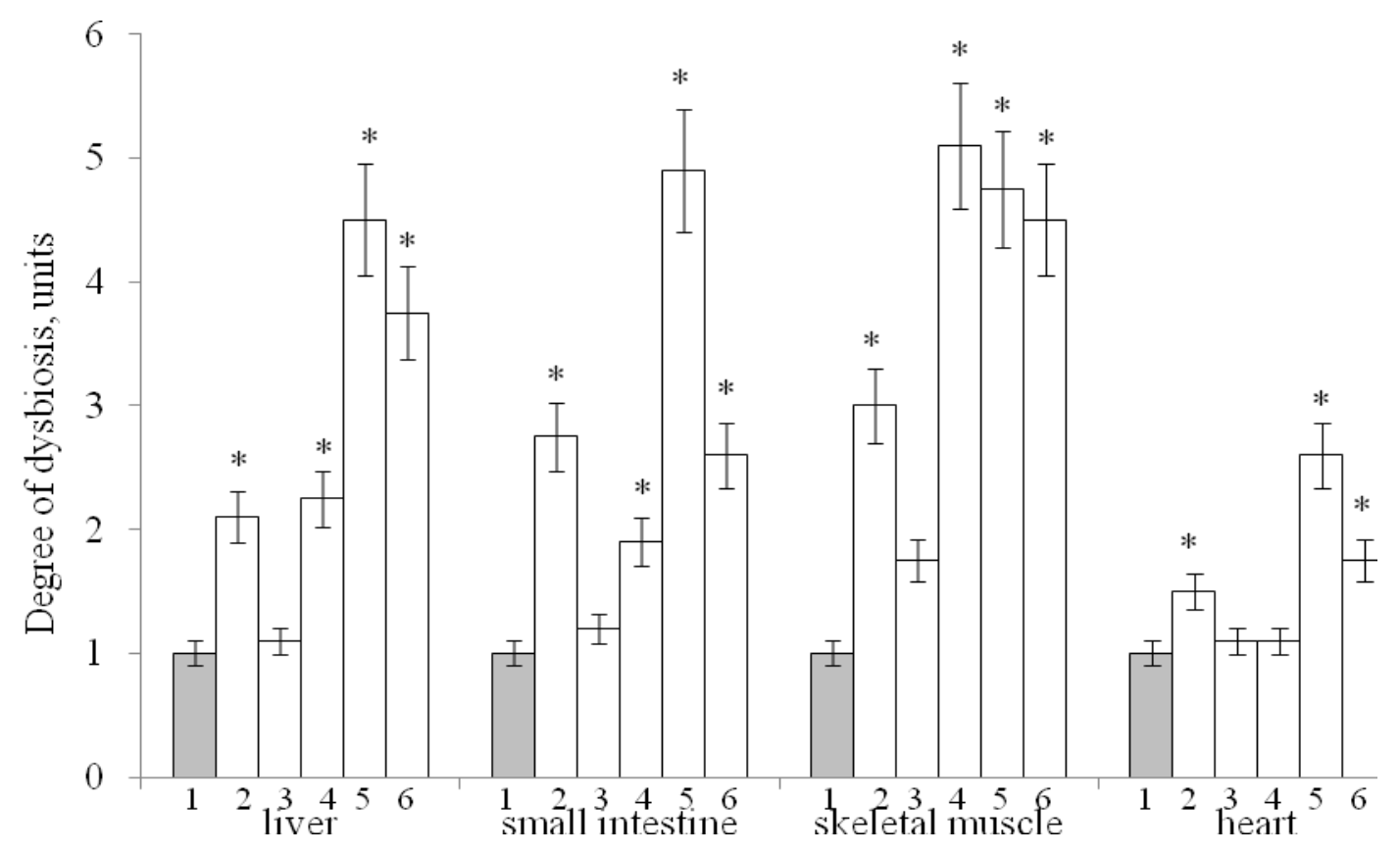

Fig. 5. Influence of HFD on the degree of dysbiosis in the organs and tissues of rats (1-6 - see Fig. 1)

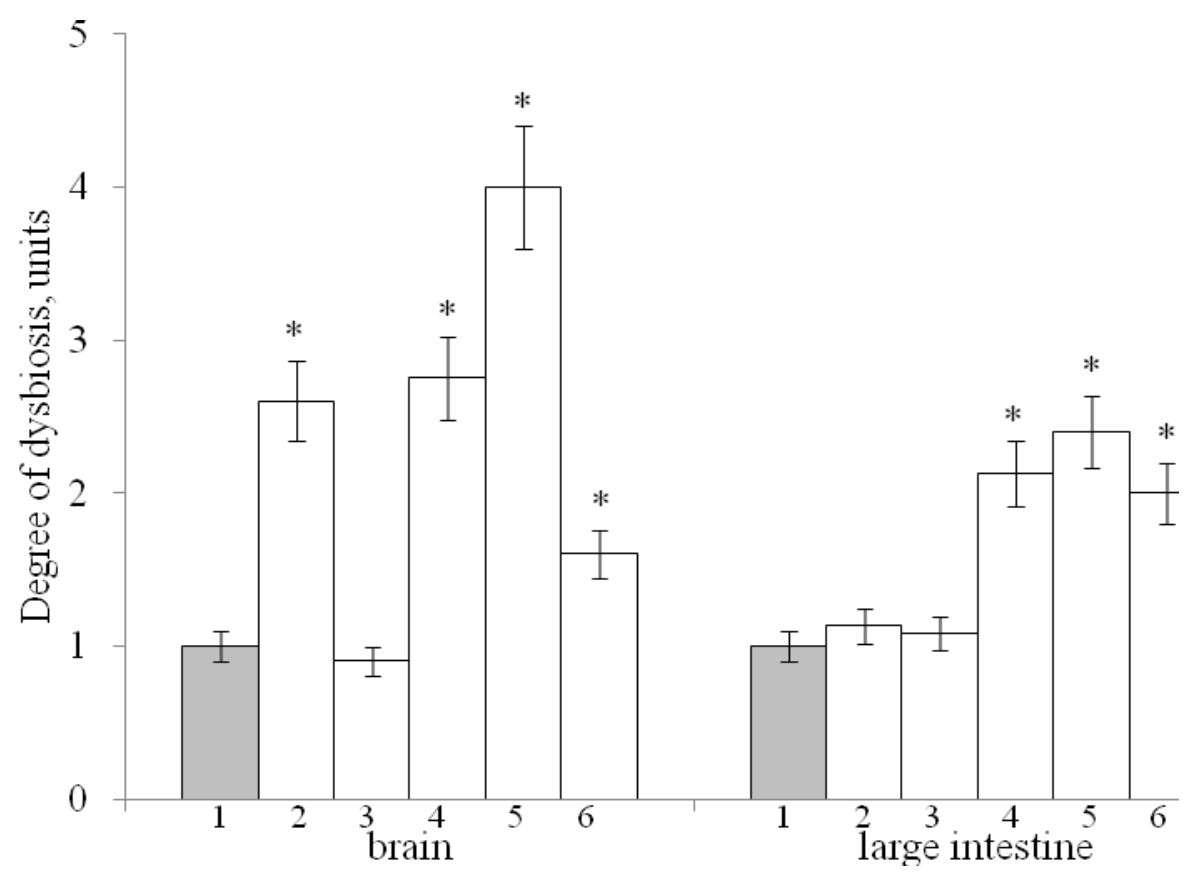

Fig. 6. Influence of HFD on the degree of dysbiosis in the organs and tissues of rats (1-6 - see Fig. 1) 
From these data, it is clear that all rats receiving HFD significantly increased the degree of dysbiosis except only those rats that received high oleic sunflower oil. Only in the skeletal muscles is there a slight increase in the degree of dysbiosis in rats treated with this oil (however $>$ $0,05)$.

Our studies have shown that HFD with the use of palm oil, ordinary (high-linoleic) sunflower oil or butter enhances the translocation of bacteria from the intestine into the blood the liver does not cope with its antimicrobial function under fat loading [16].

Additionally, FVC reduces the level of nonspecific immunity, as evidenced by a complete decrease in lysozyme activity. As a result, with dermatitis, almost all organs and tissues develop dysbiosis, which increases the risk of both local and systemic diseases.

At the same time, our work points to the possibility of avoiding the harmful effects on the body of HFD if you consume high-oleic sunflower oil, which in content of oleic acid exceeds olive oil.

\section{Conclusions}

1. High-fat diet (HFD) increases the translocation of bacteria from the gut.

2. The liver performs an antimicrobial function, as evidenced by a decrease in the activity of the bacterial enzyme urease in the blood v. cava compared to its blood level v. porta.

3. Of all dietary fats, palm and ordinary sunflower oil and butter are most likely to increase the degree of dysbiosis in the organism.

4. Consumption of high-oleic sunflower oil does not cause dysbiosis.

\section{REFERENCES}

1. Bäckhed F, Manchester JK, Semenkovich CF [and others]. Mechanisms underlying the resistance to diet-induced obesity in germ-free mice. Proc. Nat. Acad. Sci. USA. 2007; 104(3): 979-984.

2. David LA, Manrice CF, Carmody RN [and others]. Diet rapidly and reproducibly alters the human gut microbiome. Nature. 2014; 505(7484): 559-563.

3. Velichko VI, Tkachuk VV, Levitsky AP. Development of dysbiosis in tissues of rats fed with a high fat food. Journal Health Sciences. 2014; 4(2): 84-92. (in Russian) 
4. Levitsky AP, Levchenko EM, Konkin SI. Hyperlipidemic and prodysbiosis action of butter. Actual problems of transport medicine. 2014; 2(38-II)(4): 127-131. (in Russian)

5. Khodakov IV, Levitsky AP, Tkachuk VV [and others]. Prodysbiotic action of food fats with high content of palmitic acid. Bulletin of the XIV readings named after V.V. Podvysotsky. Odessa, 2015: 200-201. (in Russian)

6. Carta G, Murru E, Banni S [and others]. Palmitic acid physiological Role, metabolism and nutritional implications. Frontiers in Physiology. 2017; 8(902): 1-14.

7. Bondarenko VM, Ryabichenko EV. The role of dysfunction of intestinal barrier in the support of chronic inflammatory process of different localization. ZhMEI. 2010; 1: 92-100. (in Russian)

8. Riabchuk FN, Aleksandrova VA, Pirogova ZI. Persistent infections in children of intrauterine, neonatal and postnatal origin. SPb, 2012: 180. (in Russian)

9. Osipov GA. Metabolum - metabolic contacts of a person and his microbiota. Clinical Laboratory Diagnostics. 2016; 61(9): 545-546. (in Russian)

10. Levitsky AP, Makarenko OA, Selivanskaya IA [and others]. Enzymatic method for determining oral dysbiosis for screening pro and prebiotics: guidelines. Kiev, State Pharmacological Center, 2007: 22. (in Russian)

11. Levitsky AP, Bocharov AV, Khodakov IV [and others]. Colitis in rats fed high palmitic edible fats. Actual problems of transport medicine. 2019; 3: 120-127. (in Russian)

12. Levitsky AP, Makarenko OA, Demyanenko SA. Methods of experimental dentistry (teaching aid). Simferopol, Tarpan, 2018: 78. (in Russian)

13. Gavrikova LM, Segen IT. Urease activity of oral liquid in patients with acute odontogenic infection of maxillo-facial part. Stomatology. 1996; The extra issue :49-50. (in Russian)

14. Levitsky AP. Lysozyme instead of antibiotics. Odessa, KP OGT, 2005:74. (in Russian)

15. Truhacheva NV. Mathematical Statistics in biomedical research using application package Statistica. Moskva, GJeOTAR-Media, 2012: 379. (in Russian)

16. Levitsky AP, Demyanenko SA, Tsiselskiy YuV. The antimicrobic function of liver. Odessa, KP OGT, 2011:141. (in Russian) 